\title{
Boris Afanasyev: The alphabet man of Russian hematopoietic cell transplantation (August 28, 1947 to March 16, 2020)
}

\author{
Ludmila Stepanovna Zubarovskaya ${ }^{1} \cdot$ Ivan Sergeevich Moiseev $\mathbb{B}^{1} \cdot$ Robert Peter Gale $\mathbb{C}^{2}$
}

Received: 30 March 2020 / Revised: 1 April 2020 / Accepted: 6 April 2020 / Published online: 18 April 2020

(c) Springer Nature Limited 2020

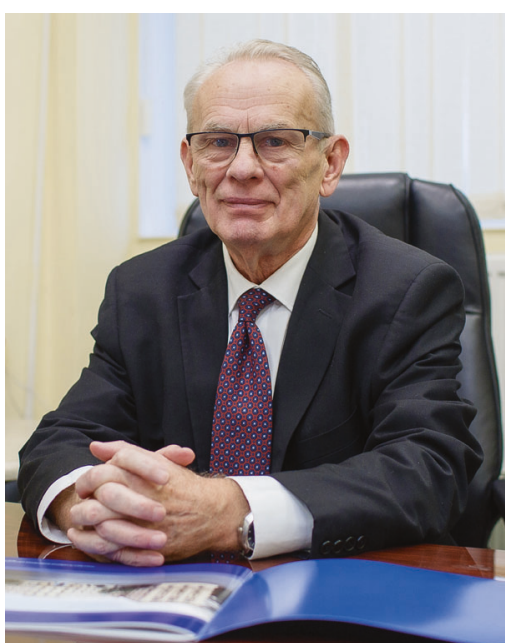

Fig. 1 Boris Afanasyev August 28, 1947 to March 16, 2020.

Professor Afanasyev, Vladimirovich Boris, the doyen of hematopoietic cell transplantation in Russia, died suddenly working at his Institute on March 16, 2020. In American idiom: He died with his boots on. Afanasyev Boris Vladimirovich (ABV), the first three letters of the Russian alphabet, was the Alphabet Man of Russian hematology. He gave his colleagues and the world the language, voice and desire to understand, treat and cure blood and bone marrow disorders (Fig. 1).

Boris was born in Latvia August 28, 1947. As a medical student in the First Pavlov Leningrad Medical Institute in 1971, he was fascinated by the mystery of hematopoietic

Ivan Sergeevich Moiseev

moisiv@mail.ru

1 R.M. Gorbacheva Memorial Institute of Children Hematology and Transplantation, Pavlov University, Saint-Petersburg, Russian Federation

2 Imperial College London, London, UK stem cells. This was a time when studies of hematopoietic stem cells were in an early stage driven by the pioneering work of Profs. McCulloch, Metcalf, Fowler, Till, and others. Boris found himself following in the footsteps of two great Russian scientists, Alexander Alexandrovitch Maximov (1874-1928), who worked in St. Petersburg Military Medical Academy and formulated the concept of stem cells, and Alexey Yakovievich Fridenshtein (1924-1997) from the Gamaleya Institute in Moscow, who formulated the concept of bone marrow microenvironment and mesenchymal stem cells. (As an aside, Friedenstein sat at the desk with Maximov's photo, his inspiration, watching the progress of his work. Inspiration or guilt; who knows?) Friedenstein became mentor and friend of Boris and encouraged Boris to pursue his interests. And off Boris went. Starting with few supplies and no equipment he developed an agar culture system which allowed him to visualize colonies of hematopoietic progenitor cells. Later it was improved into an agar drop-liquid culture which he used in his later research.

Prof. Afanasyev defended his $\mathrm{PhD}$ thesis, Cloning of hematopoietic stem cells, studies of colony-forming ability of bone marrow and blood cells from healthy persons and patients with different neutropenic conditions, in 1977. From 1976 to 1979, he headed the Department of Hematology at the Pavlov Institute Clinic. His most notable works then were studies of stem cells in culture including a description of terminal differentiation of leukemia blasts and one of the first reports of myelodysplastic syndrome in children. His habilitation thesis (1983; equivalent to a DSc.) was Granulomonocytopoiesis in acute leukemia and in blast crisis. In 1985, he published an important monograph entitled Human Hematopoietic Cells which he co-authoured with Prof. Vladimir Almazov.

The sad fate of most people with leukemia at the time caused Prof. Afanasyev to move from the laboratory to the clinic. He was inspired by the work of Prof. E. Donnall Thomas (Nobel laureate in Physiology or Medicine 1990) and colleagues who were pioneering bone marrow 
transplantation as a therapy of hematological disorders. Boris became determined to introduce this therapy into the Soviet Union. However, there were insurmountable obstacles during the Cold War and it was not until 1986 when Mikhail Gorbachev became the General Secretary of the Communist Party and began promoting glasnost that Boris could get going. The Chernobyl nuclear power facility accident in the same year brought one of us (RPG) and his team to the Soviet Union followed by a stream of transplant experts eager to share this technology with Soviet colleagues. Soon the first bone marrow transplants were done in the Soviet Union by Alexander Evgenivich Baranov at Clinical Hospital 6 in Moscow (now the Burnasyan Federal Medical Biophysical Center) in liquidators of Chernobyl nuclear power facility accident. In parallel, the Ministry of Health decided to send two stem cell researchers, Boris and Prof. Valeri Savchenko, to Seattle for a fellowship with the Thomas team. This was the beginning of hematopoietic cell transplantation in Russia. In 1987, Boris Afanasyev organized the first bone marrow transplant unit in the Soviet Union at N. Petrov Research Institute of Oncology (St. Petersburg) where the first Soviet autotransplant was done. In 1991 he performed first allotransplant in a child in Russia.

Boris' life was inextricably linked to his alma mater, Pavlov University. In 1994, he became a full professor and in 1997 moved his transplant unit there. In 2003, he organized the first faculty of hematology and transplantation for postdoctoral fellows in Russia. A major advance came in 2007 when the Mikhail Gorbachev Charity Fund gave him monies to develop the first specialized center for hematology and transplantation in Russia: the Raisa Gorbacheva Memorial Research Institute of Pediatric Oncology, Hematology and Transplantation. The Institute performs transplants for children and adults with diverse hematological disorders, especially leukemias. The unstoppable energy of Boris Afanasyev made the Institute one of the largest Europe performing around 450 transplants a year with total of $>4000$ and the central repository for data on unrelated volunteer donors in Russia. In 2018, Boris received the Clinical Achievement Award from the European Society for Blood and Marrow Transplantation. He also helped to develop a transplant unit in Kazakhstan.

Raisa Gorbacheva, the wife of Mikhail Gorbachev, was always involved in charitable activities including trying to improve hematology in the Soviet Union and was Chairperson of Hematologists of the World for Children. Ironically, in 1999, she developed acute myeloid leukemia.
She was treated by the late Prof. Thomas Büchner in Münster, Germany who was a close friend of Prof. Afanasyev. Sadly, she died.

Prof. Afanasyev had many foreign colleagues, collaborators, and friends including Axel Zander, Gerard Wagemaker, Dieter Holzer, Hans-Jochem Kolb, Nicolaus Kroeger, Rüdiger Hehlmann, Andrea Bacigalupo, Magne Børset, Jane Apperley, Tapani Ruutu, and Manuel Abecasis. A complete list would read like the United Nations. These collaborations resulted in $>70$ Russian hematologists trained in academic centers in Germany, Austria, Italy, UK, USA, and Japan and were able to build a strong transplant team in Saint-Petersburg and now head hematology and transplant departments in Saint-Petersburg at the Almazov Center, Nikiforov Center, Institute of Transfusiology and Oncology Centers in Almaty, Nur-Sultan, Surgut, and Irkutsk. It's no exaggeration to say Prof. Afanasyev created his own Russian "school of haematology".

Another of Boris' accomplishment was organizing the Neva-Wilsede meetings (1992-1993) and the subsequent annual Raisa Gorbacheva Memorial Meetings in Petersburg which became a prominent international conference. Sadly, Prof. Rolf Neth with whom Boris arranged the the NevaWilsede meetings died the same week as Boris.

Boris was an extraordinarily generous person, deeply caring for his colleagues, friends, family, and patients. For example, when one of us (ISM) completed his habitation, Boris arranged an elaborate lunch at the Chekhov restaurant in Petersburg. There were $>30$ Russian and foreign guests. Like most Russian celebrations it went on for hours. Lunch blended into dinner as the zakuska piled up and the vodka supply dwindled. Then everyone was off to the banya save Boris who returned to the Institute!

Prof. Afanasyev is survived by his wife Olga Afanasyeva, a daughter, Anastasia Afanasyeva, and two grandchildren. We miss him deeply and always will remember and cherish his legacy, especially whenever we recite the Russian alphabet.

Acknowledgements We thank friends and colleagues of Boris Afanasyev who reached us expressing their grief.

\section{Compliance with ethical standards}

Conflict of interest The authors declare that they have no conflict of interest.

Publisher's note Springer Nature remains neutral with regard to jurisdictional claims in published maps and institutional affiliations. 